No $2008-07$

April

Currency Misalignments and Exchange Rate Regimes in Emerging and Developing Countries

Virginie Coudert

Cécile Couharde 
Currency Misalignments and Exchange Rate Regimes in Emerging and Developing Countries

Virginie Coudert Cécile Couharde

No $2008-07$

April 


\section{Table of contents}

NON-TECHNICAL SUMMARY ................................................................................. 4

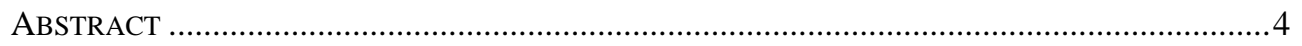

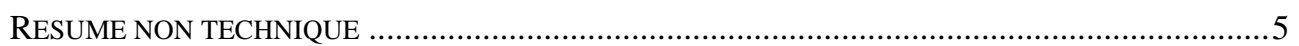

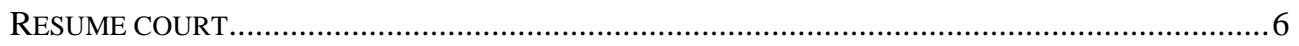

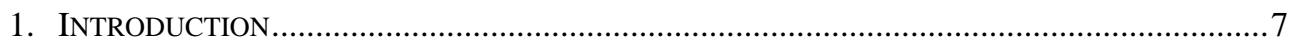

2. ASSESSING CURRENCY MISALIGNMENTS .............................................................. 9

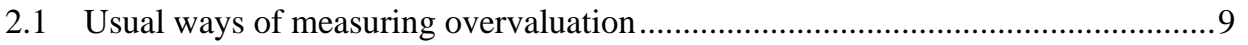

2.2 Implementing the econometric approach.................................................... 11

3. DISCRIMINATING MISALIGNMENTS ACCORDING TO EXCHANGE RATE REGIMES.................16

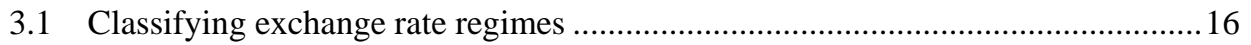

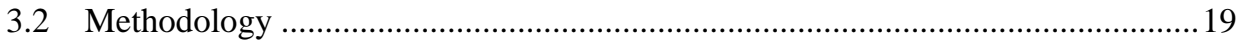

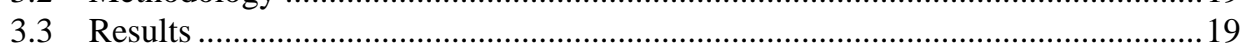

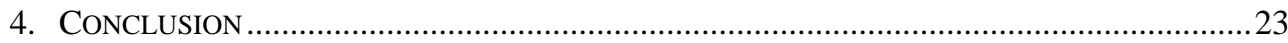

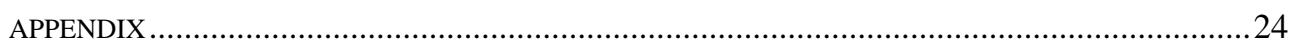

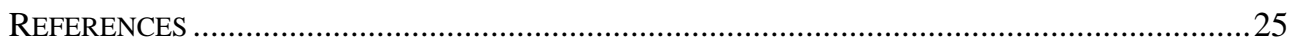

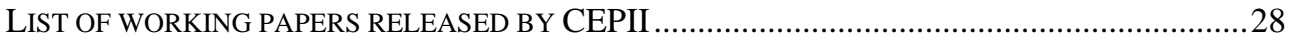




\title{
CURRENCY MISALIGNMENTS AND EXCHANGE RATE REGIMES IN EMERGING AND DEVELOPING COUNTRIES
}

\section{NON-TECHNICAL SUMMARY}

Pegged exchange rates regimes are often seen as more vulnerable to financial crises than floating ones. A standard explanation is linked to the appreciation of the real exchange rate, that may occur in these regimes. In this case, the ensuing loss of competitiveness erodes the external competitiveness and the current account balance, which can lead to financing difficulties or even to a speculative attack. This problem is more acute for emerging and developing countries, for they are more likely to adopt a "de facto" fixed exchange rate as evidenced by Reinhart (2000).

The aim of this paper is to check if pegged exchange rates are more prone to overvaluation than other types of regimes. We begin by assessing currency misalignments choosing a standard econometric approach over a large sample of 128 countries from 1974 to 2004. We estimate real equilibrium exchange rates by two econometric relationships: the first takes into account a sheer Balassa effect; the second one adds to the former equation the impact of net foreign assets. The currency misalignment is defined by the gap between the observed real exchange rate and the estimated equilibrium exchange rate. When using successively the two equilibrium exchange rate models, we have two sets of currency misalignments over our sample.

We then compare these misalignments across exchange rate regimes. We use two databases on "de facto" exchange rate regimes classifications, the one developed by Levy-Yeyati and Sturzengger (2003) and the other one provided by Reihnart and Rogoff (2004). Pegged currencies are shown to be significantly more overvalued than floating ones. This result is true with both equilibrium exchange rate models. It is also confirmed, when changing classification method.

\begin{abstract}
Pegged exchange rates are often pointed out as more prone to risk of overvaluation, because their real exchange rates have a tendency to appreciate. We check this assumption empirically over a large sample of emerging and developing countries, by using two databases for de facto classifications by Levy-Yeyati and Sturzenegger (2003) and by Reinhart and Rogoff (2004). We assess currency misalignments by estimating real equilibrium exchange rates taking into account a Balassa effect and the impact of net foreign assets. Pegged currencies are shown to be more overvalued than floating ones.
\end{abstract}

JEL Classification: F31, F33

Key Words: $\quad$ Exchange Rate Regimes, Emerging and developing countries, Misalignments 


\section{MESALIGNEMENTS DE TAUX DE CHANGE ET REGIMES DE CHANGE DANS LES PAYS EMERGENTS ET EN DEVELOPPEMENT}

\section{RESUME NON TECHNIQUE}

Les régimes de change fixe sont souvent jugés plus vulnérables aux crises financières. Une des principales faiblesses, souvent mise en exergue, d'un ancrage du taux de change, semble résider dans l'appréciation du taux de change réel. La perte de compétitivité, qui en découle, peut aboutir à creuser un déficit de la balance courante, et conduire soit à des difficultés de financement, soit à une attaque spéculative. Cette question se pose d'une manière particulièrement cruciale pour les économies émergentes ou en développement, où la «peur du flottement» (Reinhart 2000) a souvent conduit à l'adoption de régimes de change fixe de facto.

L’objectif de ce papier est de vérifier si les régimes de change fixes sont, plus que les autres régimes, enclins à induire une surévaluation réelle des monnaies. Nous estimons tout d'abord des distorsions de taux de change réels sur un échantillon de 128 pays et sur la période 1974-2004 en testant deux équations réduites du taux de change réel. La première prend en compte un effet Balassa-Samuelson, la seconde retient une seconde variable explicative, la position extérieure nette. Les mésalignements sont définis par les écarts entre les taux de change réels observés et leur valeur d'équilibre estimée. En utilisant successivement les deux modèles de taux de change d'équilibre, nous disposons donc de deux ensembles de mésalignements sur notre échantillon.

Nous comparons ensuite ces mésalignements selon le régime de change des pays, par un test de comparaison de moyennes. Nous utilisons deux classifications des régimes de change de facto, l'une établie par Levy-Yeyati et Sturzenegger (2003), l'autre par Reinhart et Rogoff (2004). Nos résultats montrent que les économies émergentes ou en développement ayant opté pour un régime de change fixe se caractérisent, en moyenne, par une surévaluation de leur taux de change réel. Ce résultat est confirmé avec les deux taux de change d’équilibre. Il est aussi vérifié dans les deux classifications considérées. 


\section{RÉSUME COURT}

Les régimes de change fixe sont souvent considérés comme particulièrement enclins à induire des surévaluations réelles, en raison de l'appréciation du taux de change réel qu'ils peuvent provoquer. Nous vérifions cette hypothèse sur un large échantillon d'économies émergentes ou en développement, en utilisant deux classifications différentes des régimes de change de facto, l'une proposée par Levy-Yeyati et Sturzenegger (2003), l'autre par Reinhart-Rogoff (2004). Les mésalignements de taux de changes réels sont obtenus par l'estimation de taux de change réels d'équilibre qui prennent en compte un effet Balassa et l'impact de la position extérieure nette. Nous montrons que les pays en régime de change fixe se caractérisent, en moyenne, par une surévaluation de leur taux de change réel par rapport aux pays en changes flottants.

Classification JEL: F31, F33

Mots clefs:

régimes de change, économies émergentes et en développement, mésalignements 


\title{
CURRENCY MISALIGNMENTS AND EXCHANGE RATE REGIMES IN EMERGING AND DEVELOPING COUNTRIES
}

\author{
Virginie Coudert ${ }^{1}$ and Cécile Couharde ${ }^{2}$
}

\section{INTRODUCTION}

The most devastating currency crises of the last decades occurred in contexts where fixed exchange rates, using the term in its broadest sense, were in place. This was true of the 1992-1993 crises in the European Exchange Rate Mechanism, of Mexico in 1994-95, South-East Asia in 1997, Russia in 1998, Brazil in 1999, Turkey in 2001, Argentina in 2002. Now, emerging economies have been warned off any type of fixed system, which is unilaterally set, and urged instead to have more flexible currencies. In all the examples cited above, the exchange rates were either fixed (maintained within fluctuation bands around a central parity) or in a crawling peg (pegged to a reference rate that is devalued regularly according to a pre-announced schedule) in the years leading up to the crises: Asian currencies had de facto pegs against the USD; Mexico and Turkey had crawling pegs in place; Argentina had a currency board.

There are two possible explanations for these crises to have occurred in pegged exchange rates regimes. A first explanation is linked to a possible currency overvaluation. This is in line with the empirical literature on currency crises, which finds the real exchange rate appreciation to be an early signal of currency crises (Kaminsky et al., 1998; Burkart and Coudert, 2000; Bussière and Fratzscher, 2006). The fact that the exchange rate was fixed in the years leading up to the crisis could have caused the country's real exchange rate to appreciate, thereby eroding the external competitiveness and the current account balance.

A second explanation is linked to a possible sample bias. Crises occurred in fixed exchange rate regimes, just because most emerging countries were having pegged currencies at that time. Indeed, this was well evidenced by many papers especially the one entitled "Fear of Floating” by Calvo and Reinhart (2002). However, the fact that most emerging countries switched to floating currencies in the late 1990s is not sufficient to reassure us against the possibility of new currency crises. Indeed, events such as the sharp fall of the Turkish lira in June 2006 remind us that this danger has not been eradicated.

\footnotetext{
${ }^{1}$ Virginie Coudert, Bank of France and CEPII, virginie.coudert@banque-france.fr postal address : Bank of France, code 35-1537, 31 rue Croix des Petits Champs, 75001 Paris, France, tél.: 0033142924292, fax : 0033142924867

Cécile Couharde, University of Versailles Saint Quentin, C3ED, cecile.couharde@uvsq.fr

- We thank Valérie Mignon and Thomas Heckel for their helpful comments on a former version of the paper.
} 
This paper sets out to look into these explanations and check if pegged exchange rates are really more prone to overvaluation than other types of regimes. We revisit the question of the real exchange rate behaviour under different exchange rate regimes, by using two databases on de facto classifications, the one by Levy-Yeyati and Sturzengger (2003) and the other one provided by Reinhart and Rogoff (2004).

Fixed exchange rates cause the real exchange rate to appreciate, each time inflation is higher than in the country issuing the anchor currency. Such situations occur regularly, because fixed exchange rates are often introduced as a means of combating high inflation. As inflation falls only gradually after the peg has been created, the currency appreciates in real terms. For example, Goldfajn and Valdés (1996) find that real exchange rates have a tendency to appreciate under fixed exchange rate regimes. However, there is also a wealth of empirical research to show that floating exchange rates not only fail to cushion emerging economies from shocks, but even tend to amplify them (Hausmann et al., 1999; Calvo and Reinhart, 2000, 2002). This raises the possibility of misalignment for floating exchange rates. Indeed, there is no empirical evidence showing that floating exchange rates are less misaligned than fixed ones.

Real exchange rate overvaluation refers to a situation in which a country's real exchange rate is more appreciated than its equilibrium level. The latter is generally defined as the real exchange rate that, for given values of fundamentals, is consistent with the simultaneous achievement of internal and external equilibria. After the Mexican crisis in 1995 and East Asian crises in 1997, which were often imputed to overvaluation, economists have stepped up efforts for finding methodologies in order to assess real exchange rate misalignment in emerging economies. Empirical works can be split in two main streams. First, a macroeconomic approach, called FEER (Fundamental Equilibrium Exchange Rate), relates the equilibrium exchange rate to a structural current account target (Williamson, 1994; Isard and Faruqee, 1998; Isard, 2007). Second, an econometric approach, also mentioned as BEER (Behavioural Equilibrium Exchange Rate), relies on an econometric estimation of a long run relationship between the exchange rate and fundamentals (Clark and MacDonald, 1998; Alberola et al., 1999; Chinn, 2000). We briefly survey these methodologies, and then choose a standard econometric approach, which can be applied to a large set of countries. This allows us to compute misalignments. After that, we use the databases on the exchange rate regimes to test if overvaluation is more pronounced in countries with pegged exchange rates rate than in floating regimes.

The rest of the paper is organised as the following. Section 2 justifies and describes the method for assessing currency misalignments. In section 3 , we test if there is a difference in these misalignments according to the exchange rate regime. Section 4 concludes. 


\section{ASSESSING CURRENCY MISALIGNMENTS}

A currency misalignment can be defined as a gap between a country's real exchange rate and its equilibrium level. There are different ways of measuring equilibrium real exchange rates, from purchasing power parity, to FEERs and econometric approaches.

\subsection{Usual ways of measuring overvaluation}

\section{Relative purchasing power parity}

The relative purchasing power parity (PPP) hypothesis states that the real exchange rate (RER) is stationary, and therefore mean-reverting. In this framework, deviations of the real exchange rate from its long-run average can be considered as misalignments that are likely to be corrected in the future.

The real exchange rate $q_{t}$ is defined as:

$q_{t}=e_{t}+\left(p_{t}-p_{t}^{*}\right)$

where $e_{t}$ is the nominal exchange rate, $p_{t}$, the home country's consumer price index (CPI) and $p_{t}^{*}$ the foreign country's CPI. All variables are indices, based at 100 in a benchmark period and taken in logarithm. An increase in real and nominal exchange rates stands for an appreciation.

The misalignment $m_{t}$ is then calculated as the difference between the real exchange rate at time $t$ and its empirical long-term average, $\bar{q}_{t}$

$m_{t}=q_{t}-\bar{q}_{t}$

$\bar{q}_{t}=\frac{1}{t-t_{0}+1} \sum_{\tau=t_{0}}^{t} q_{\tau}$

where $t_{0}$ stands for the beginning of the period for calculating the empirical mean.

A large number of empirical studies have relied on this simple calculation. For example, the economic literature on early warning systems has used it as an advanced indicator of currency crises (Kaminsky, Lizondo and Reinhart, 1998; Bussière and Fratzscher, 2006). 
One severe drawback of this method is that the PPP hypothesis has received only mixed support from empirical works (Rogoff, 1996; Edwards and Savastano, 1999). If PPP hypothesis does not hold, the empirical average calculated in equation (3) is not meaningful, as real exchange rates are not mean-reverting. Even if PPP holds, the mere calculation by equation (3) is still problematic: it is not possible to calculate the mean on a short period of time, as half life deviations are rather long, between 3 to 5 years; however, taking longer periods also runs the risk of breaking points and structural changes between different historical periods.

\section{The macro-economic approach of equilibrium exchange rates}

The macroeconomic approach was pioneered by Williamson (1994) and is still used at the International Monetary Fund (Isard, 2007). It relies on defining a Fundamental Equilibrium Exchange Rate, which allows the economy to reach both its internal and external equilibria. Internal balance is defined by full employment within a low inflation environment; external balance can be characterized in two ways: by a current account in line with fundamentals, such as given in empirical estimations of saving-investment balances across countries (Chinn and Prasad, 2003); or by a current account which is consistent with external debt sustainability in the spirit of Milesi-Ferretti and Razin (1996). Calculating FEERs amounts to finding the real exchange rate that allows the underlying current account ${ }^{3}$ to reach its target. This requires econometric estimates of trade elasticities.

Although the methodology has great advantages, mainly because its results are easy to interpret, there are a few shortcomings in applying it to emerging and developing countries. Firstly, results are sensitive to the trade elasticities, which are usually taken as an average on a large set of countries (Isard, 2007). Secondly, internal imbalances, usually measured by output gaps, are awkward to compute for emerging countries. Isard and Faruqee (1998) recommend computing them through a Hodrick-Prescott filter, but this method is not very reliable over short samples and lack theoretical foundations. More generally, the concept of output gap may not be appropriate for emerging and transition countries as their economic transformations are still in progress (Coudert and Couharde, 2007). Thirdly, estimating the external equilibrium also raises thorny issues. On the one hand, the assumption of external debt sustainability usually ends up in maintaining the former level of debt (IMF, 2007), whatever its size, which leads to large unexplained differences between countries. On the other hand, running a cross-country regression to estimate equilibrium current accounts can result in sharp differences with the observed data, and therefore in large misalignments.

\section{The econometric approach}

Given all the snags in defining internal and external equilibria for emerging countries, the empirical literature has often relied on direct econometric estimations. This approach is often called Behavioral Equilibrium Exchange Rate (BEER) following Clark and MacDonald (1998). The econometric approach focuses on estimating a reduced form

\footnotetext{
3 i.e. the current account that would be observed if there were no output gaps and the past changes in the exchange rates had already had their entire effects.
} 
equation between the real exchange rate and its fundamentals (Edwards, 1997; Montiel, 1999a; Chinn, 2000). Although it is often merely empirical, it may rely on theoretical models as in Edwards (1994) and Montiel (1999b), who developed intertemporal general equilibrium models. In these models, the equilibrium exchange rate is defined as the relative price of tradables to non-tradables that, ceteris paribus, results in the simultaneous attainment of internal and external equilibria. Rigorously, the calculations would require estimating a computable equilibrium general model or at least the supply and demand functions for tradables and non tradables. In practice, the method amounts to estimating a reduced-form relationship between the real exchange rate and some fundamental variables:

$q_{t}=\alpha_{0}+\sum_{j=1}^{J} \alpha_{j} x_{j t}+\varepsilon_{t}$

where $x_{j t}$ are $J$ fundamental variables, $\varepsilon_{t}$, the error-term of the equation, and $\alpha_{j}$ the coefficients to estimate.

As the series are generally found to be non stationary, this equation stands for a long-run relationship if the series are cointegrated.

The equilibrium exchange rate is defined as the fitted value of the regression, using the long-run values of the fundamentals $\bar{X}_{j t}$ :

$\bar{q}_{t}=\hat{\alpha}_{0}+\sum_{j=1}^{J} \hat{\alpha}_{j} \bar{x}_{j t}$

The misalignment is then defined as the gap between the real exchange rate and its equilibrium value, as in equation (2).

\subsection{Implementing the econometric approach}

The dependent variable: the real exchange rate

Here, we use exchange rates in levels, as calculated through the International Comparison Program (ICP) by the World Bank (World Bank, 2007), rather than in indices. The ICP data provide relative prices between countries, which can be seen as real exchange rates. The advantage is that cross-country differences in real exchange rates are meaningful, contrary to the exchange rate indices or variations. It is also the approach followed by Cheung, Chinn and Fujii (2007), as well as Rodrik (2007). The dollar is used as a numeraire. ${ }^{4}$ A

The choice of the dollar as a numeraire instead of effective real exchange rates is linked to the tradeoff between a large sample of countries (128), which we consider more likely to give robust results, and the fact that the trade structure is not available for such a large number of countries, which prevents the construction of effective exchange rates. 
country's real exchange rate is defined by dividing its international price level by the US one. Explanatory variables are also defined in levels and taken relatively to the US.

\section{The fundamentals}

One of the key fundamental variables in most empirical papers is the Balassa-Samuelson effect (Edwards and Savastano, 1999; Chinn, 2000; Cheung, Chinn and Fujii, 2007; Rodrik, 2007; Isard, 2007; Bénassy-Quéré et al., 2008). It states that the more productive the tradable sector is relatively to the non tradable sector, the more appreciated the real exchange rate should be. As productivity data by sector are not available for a sufficient number of countries, we proxy the Balassa effect by the PPP GDP per capita.

Another key variable is the country's net foreign assets in percentage of GDP. As the net foreign assets (NFA) owned by a country increase, its capital income is boosted, as well as its current account. Hence, its equilibrium exchange rate may appreciate, without impeding the current account. This variable is also commonly found in the literature on equilibrium exchange rates (Alberola et al., 1999; Bénassy et al., 2004; Isard, 2007).

To check the validity of the results, we successively use two types of estimations. The first one only includes a Balassa effect:

$q_{i t}=\beta_{0 i}+\beta_{1} y_{i t}+\varepsilon_{i t}$

(Model 1)

where $q_{i t}$ is country i's real exchange rate in level, equal to country i's price level relatively to the US, taken in logarithm; $y_{i t}$ is the PPP GDP per capita relatively to the US, taken in logarithm, $\beta_{0 i}$ and $\beta_{1}$, parameters to estimate.

The second model adds to the first one the country's NFA position:

$q_{i t}=\gamma_{0 i}+\gamma_{1} y_{i t}+\gamma_{2} a_{i t}+\eta_{i t}$

(Model 2)

where $a_{i t}$ is country $i$ 's net foreign assets in percentage of GDP minus the US net foreign assets in $\%$ of GDP, $\gamma_{0 i}, \gamma_{1}$ and $\gamma_{2}$, parameters to estimate.

\section{The sample}

Here we consider the broadest sample as possible to calculate these misalignments. The sample includes 128 countries over the period 1974-2004. Prices in international comparison and PPP GDP levels are extracted from the CEPII-CHELEM database. Net foreign assets come from Lane and Milesi-Ferretti's database (Lane and Milesi-Ferretti, 
2007). As there are some missing data for some countries on the whole period, the panel is unbalanced. Appendix gives the list of countries.

\section{Panel unit root and cointegration tests}

The method consists in estimating models (1) and (2) through panel cointegration analysis. We begin by performing panel unit-root tests.

Consider a following AR(1) process for panel data:

$x_{i t}=\rho_{i} x_{i t-1}+\sum_{l=1}^{L} \delta_{i}^{l} z_{i t}^{l}+\varepsilon_{i t}$

where $i=1,2, \ldots ., N$ stands for the country, and $t=1,2, \ldots ., T$ for the time dimension, $z_{i t}^{l}$ are $L$ exogenous variables, including any fixed effects or individuals trends, $\rho_{i}$ are the autoregressive coefficients, and the errors $\varepsilon_{i t}$ are assumed to be mutually independent idiosyncratic disturbances.

If $\rho_{i}=1, y_{i}$ has a unit root. If $\rho_{i}<1, y_{i}$ is considered weakly (trend-) stationary. Two kinds of assumption can be made about the $\rho_{i}$. One can assume that they are common across cross-sections so that $\rho_{i}=\rho$ for all $i$, as in the Levin, Lin, and Chu (LLC), Breitung, and Hadri's tests. Or one can allow them to be different across crosssections, as in the Im, Pesaran, and Shin (IPS), and Fisher-ADF and Fisher-PP tests. All panel unit root tests have a null hypothesis of a unit root, except the Hadri test.

Table 1 shows the results of the tests. The LLC and the Breitung test lead to reject the null of a unit root for the real exchange rate; this is also true for net foreign assets, when using the Breitung test. However, this could be due to their restrictive hypothesis of common coefficients $\rho_{i}$ across countries. All the other tests shows that the null of a unit root cannot be rejected for each of the three series. The Hadri test also goes the same way, as it leads to reject the hypothesis of no unit root. 
Table 1: Panel unit root tests

\begin{tabular}{|c|c|c|c|c|c|c|}
\hline \multirow[t]{2}{*}{ Method } & \multicolumn{2}{|c|}{$\begin{array}{c}\text { Real exchange rate in } \\
\text { level }\end{array}$} & \multicolumn{2}{|c|}{ PPP GDP per capita } & \multicolumn{2}{|c|}{$\begin{array}{l}\text { Net foreign assets } \\
\text { in \% of GDP }\end{array}$} \\
\hline & Statistic & P. value. & Statistic & P. value & Statistic & P. value \\
\hline \multicolumn{7}{|l|}{ Null: Unit root } \\
\hline Levin, Lin \& Chu test & -2.99 & 0.0014 & 1.40 & 0.9196 & 0.42 & 0.6632 \\
\hline Breitung t-stat & -3.48 & 0.0003 & 1.98 & 0.9759 & -1.57 & 0.0579 \\
\hline Im, Pesaran and Shin W-stat & 1.726 & 0.9578 & -0.05 & 0.4794 & 1.28 & 0.8992 \\
\hline ADF - Fisher Chi-square & 252.43 & 0.9887 & 316.92 & 0.3217 & 263.94 & 0.4204 \\
\hline PP - Fisher Chi-square & 228.19 & 0.9997 & 336.42 & 0.1117 & 205.12 & 0.9949 \\
\hline \multicolumn{7}{|l|}{ Null: No unit root } \\
\hline Hadri Z-stat & 18.183 & 0.0000 & 12.08 & 0.0000 & 26.38 & 0.0000 \\
\hline
\end{tabular}

With individual linear trends and intercepts for the 3 variables. Lags are selected with modified AIC for RER and GDP, SIC for NFA.

Source: authors' calculations

To perform panel cointegration tests, we apply the seven tests proposed by Pedroni (1999). The estimated relationship is the following one:

$$
q_{i t}=\varphi_{0 i}+\mu_{i} t+\varphi_{1 i} y_{i t}+\varphi_{2 i} a_{i t}+\eta_{i t}
$$

where $\varphi_{0 i}, \varphi_{1 i}, \varphi_{2 i}$ are parameters to estimate, $\mu_{i} t$ individual time effects.

Among the seven Pedroni's tests, four are based on the within dimension (panel cointegration tests) and the three others on the between dimension (group mean panel cointegration tests). All the tests have the null hypothesis of no cointegration for all countries. Under the alternative hypothesis, for the panel statistics, there is cointegration for all countries. However, the group mean panel cointegration statistics allow for heterogeneity across countries under the alternative hypothesis. Table 2 displays the results of Pedroni's tests. Most panel and group mean statistics reject the null hypothesis of no cointegration at the 5\% significance level. Therefore, it seems reasonable to proceed under the assumption that the variables are cointegrated. 
Currency Misalignments and Exchange Rate Regimes in Emerging and Developing Countries

Table 2: Pedroni cointegration test

\begin{tabular}{cccccccc}
\hline & \multicolumn{4}{c}{ Panel cointegration tests } & \multicolumn{3}{c}{ Group mean cointegration tests } \\
\hline & v-stat & rho-stat & $\begin{array}{l}\text { PP- } \\
\text { stat }\end{array}$ & ADF-stat & rho-stat & PP-stat & ADF-stat \\
\hline Model 1 & 1.51 & $2.39^{* * *}$ & 0.58 & $-2.38^{* * *}$ & $5.90^{* * *}$ & $2.47^{* * *}$ & $-3.36^{* * *}$ \\
Model 2 & $2.25^{* *}$ & $3.66^{* * *}$ & 0.75 & $-1.62^{* * *}$ & $7.38^{* * *}$ & 1.41 & $-4.63^{* * *}$ \\
\hline
\end{tabular}

** Rejection of the null hypothesis of no cointegration at a 5\% significance level;*** at a $1 \%$ significance level

Source: authors' calculations

In order to estimate the cointegration vectors, we use the Fully-Modified Ordinary Least Squares (FM-OLS) pioneered by Pedroni (2000). The cointegration vectors obtained are displayed in Table 3. In both models, the explanatory variables are significant and correctly signed. The coefficients of the Balassa effect in the two models are between 0 and 1 , as expected (see for example Rogoff, 1996). Therefore, both of them seem appropriate to assess equilibrium exchange rates.

Table 3: Cointegration vector, panel estimations

\begin{tabular}{lcc}
\hline & Relative PPP GDP per capita & Net foreign assets \\
\hline Model 1 & 0.49 & - \\
& $(13,99)$ & 0.13 \\
Model 2 & 0.26 & $(9.17)$ \\
& $(7.21)$ & \\
& t-statistic is given in brackets. \\
& Source: authors' calculations
\end{tabular}

\section{The misalignments}

We calculate two real equilibrium exchange rates by using successively the two models. They are obtained as the product of the cointegrating vectors and the fundamental variables. The misalignments are calculated as the difference between the observed real exchange rate and the equilibrium exchange rate. As an increase in the real exchange rate stands for an appreciation, a positive misalignment means an overvaluation.

Putting individual fixed effects in the models would amount to setting to zero the average misalignment on the time sample for each country, which is an assumption frequently made 
when working with exchange rate indices. Here, we retain a common intercept: $\beta_{0 i}=\beta_{0}$ in Model 1 and $\gamma_{0 i}=\gamma_{0}$ in Model 2.. The mean misalignment is therefore null for the whole sample, but not necessarily for each individual country. The aim is to preserve the cross-section dimension of the data, as we use international price comparisons, which differences are relevant across countries. In this way, a given country may have a positive or negative mean misalignment according to its price levels and its fundamentals compared to the others.

\section{DISCRIMINATING MISALIGNMENTS ACCORDING TO EXCHANGE RATE REGIMES}

De facto classifications for exchange rate regimes have been important since the seminal paper by Calvo and Reinhart (2000, 2002), that emphasised the existence of "disguised fixed exchange rates". By this term, they pointed out regimes, which are announced as floating to the IMF "de jure classification", but are de facto pegged by the monetary authorities. The authors explained this finding by what they called a generalized "fear of floating" among developing and emerging countries. Since then, the IMF "de jure" classification has not been considered as reliable ${ }^{5}$ and identifying "de facto" exchange rate regimes became an important issue.

\subsection{Classifying exchange rate regimes}

\section{Existing classifications}

De facto classifications are based on the observation of data. The basic idea underlying their conception is that in a fixed exchange rate regime, the exchange rate should evidence a low volatility and the country's official reserves are likely to fluctuate a lot, as interventions on the forex market are often necessary to defend the parity. Conversely, floating exchange rates have a high volatility, and nearly no variations in official reserves. Intermediate regimes, such crawling pegs or managed floats, have tepid fluctuations on both variables. Several methods exist for identifying the exchange rate regimes.

The Levy-Yeyati and Sturzenegger (2003, 2005), also called "LYS" classification, is based on a statistical analysis of the regimes used worldwide. It relies on a cluster analysis of three annual variables: the annual average of the absolute monthly percentage changes in the exchange rate, its standard deviation and the average of the monthly percentage changes in official reserves. The classification, developed by Reinhart and Rogoff (2004), that we will call "RR" classification from now on, relies only on the exchange rate variation, but it improves on existing methods by using parallel exchange rates for countries where there is a dual currency market. Although other methods of classification have been proposed (Poirson, 2001; Bubula and Ötker-Robe, 2002; Dubas et al, 2005), we focus on the two main ones, "LYS" by Levy-Yeyati and Sturzenegger and "RR" by Reinhart and Rogoff, as they are widely-used and their results, available on the internet.

${ }^{5}$ Taking account this issue, the IMF has revised its classification since then. 


\section{Data and sample}

We have extracted the exchange rate regime dummies from the LYS and RR classifications. We consider three types of exchange rate regimes (ERR): pegged exchange rates, intermediate regimes (that include crawling pegs and managed floats) and floating exchange rates. This typology fits the LYS 3-way classification exactly. For the RR classification, we had to put together some categories from the coarse classification ${ }^{6}$. The LYS classification covers the period from 1974 to 2004 on an annual basis, the RR classification goes from 1974 up to 2001. For our sample of 128 countries, only half of the observations are classified in the same category by the two classifications. The RR classification identifies much fewer fixed exchange rate regimes (867 against 1645) than the LYS one (Figure 1). This is not surprising, as they use parallel market rates, which are known to be more flexible than official rates, used by LYS. For the same reason, the number of intermediate regimes is greater in the RR classification.

\footnotetext{
${ }^{6}$ The RR coarse classification includes 6 categories. : we have kept category 1 as fixed; put together categories 2 (crawling peg) and 3 (crawling bands and managed floats) as intermediate; and also brought together categories 4 (freely floating) and 5 (freely falling) as floating.
} 
Figure 1: Distribution of Exchange Rate Regimes according to the two classifications (1)

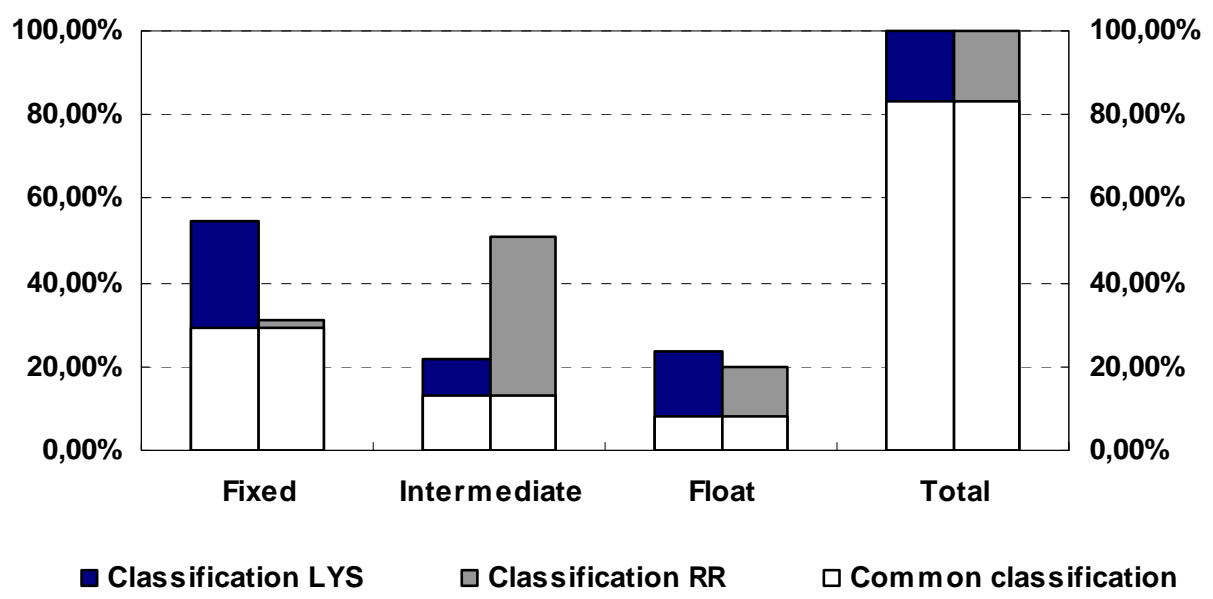

(1) The white part of each bar shows the share of the observations that are classified in the same category in both classifications; for the total, it shows the share of observations which are classified in the two classifications (although possibly not in the same category).

Source: authors' calculations, from the databases by Levy-Yeyati and Sturzenegger, Reinhart and Rogoff

Until now, we have worked on the largest sample as possible, in order to get reliable estimates for misalignments. However, we are only interested in the developing and emerging countries, more specifically, our focus is to determine if their currencies are more likely to be overvalued in pegged exchange rate regimes. Consequently, from now on, we work on a reduced sample, only including countries with PPP GDP per capita smaller than $70 \%$ of the United States' level in 2000 (see Appendix). This leaves us now with 108 countries. To be sure that our results on misalignments are still valid on this smaller sample, we have redone all the previous econometric tests. We have checked that our variables are still non-stationnary and cointegrated in the two models. Moreover, the coefficients of the cointegration vector are exactly the same for Model (1), or very close for Model (2) ${ }^{7}$, which ensures that the previous misalignments can be applied in this new sample.

\footnotetext{
${ }^{7} 0.25$ instead of 0.26 for relative GDP per capita, and 0.12 instead of 0,13 for net foreign assets. Detailed
} results are available upon request to the authors. 


\subsection{Methodology}

We compare the RER misalignments previously obtained across the three exchange rate regimes: pegged, intermediate and floating. These series are stationary by construction, as the residuals of a cointegration relationship. Thus, we can compute their average over the whole sample and by category of ERR. We then perform a mean comparison test to check if the results are significantly different between the sub-samples of pegs and floating ERR.

The null hypothesis $H_{0}$ is that the mean of misalignment is equal in the sub-sample of pegged ERR (respectively, intermediate) and floating exchange rates. Here we use the floating ERR as a benchmark. Let's call $\bar{X}_{k}$ the empirical mean of misalignments over the exchange regime $k$ ( $\mathrm{k}=$ pegged, intermediate) and $\bar{X}_{0}$ their mean over the floating ERR. We compute a test of mean differences.

$t=\left(\bar{X}_{k}-\bar{X}_{0}\right) / \sqrt{\bar{S}_{k}^{2} / n_{k}+\bar{S}_{0}^{2} / n_{0}}$

where $\bar{S}^{2}{ }_{k}$ is the empirical variance over the exchange regime $k$, and $n_{k}$ the size of the sub-sample $k . \bar{S}_{0}^{2}, n_{O}$ stand for the same statistics for the floating exchange rates.

\subsection{Results}

Results show that misalignments are very different across currency regimes. Pegged currencies are found overvalued, unlike the other categories; floating exchange rates allow the most undervalued currencies, while intermediate regimes lie somewhere in between, with undervalued currencies but to a lesser extent (Figure 2).

With the LYS classification, fixed exchange rates regimes lead to currencies being overvalued by $12 \%$ in model 1 and by $5 \%$ in model 2 on average on the sample. On the opposite, floating exchange rates regimes are associated with the largest undervaluation by 14 or $17 \%$ according to the model; intermediate regimes also give way to undervalued currencies, but to a lesser extent by $10 \%$ to $14 \%$. The results are analogous when using the RR classification: pegs are also found overvalued by $18 \%$ and $9 \%$ in the two models; floating currencies are undervalued by $18-19 \%$. 
Figure 2: Overvaluation by category of ERR, in \% (1), according to models 1 and 2 in LYS and RR classifications

\section{LYS classification}

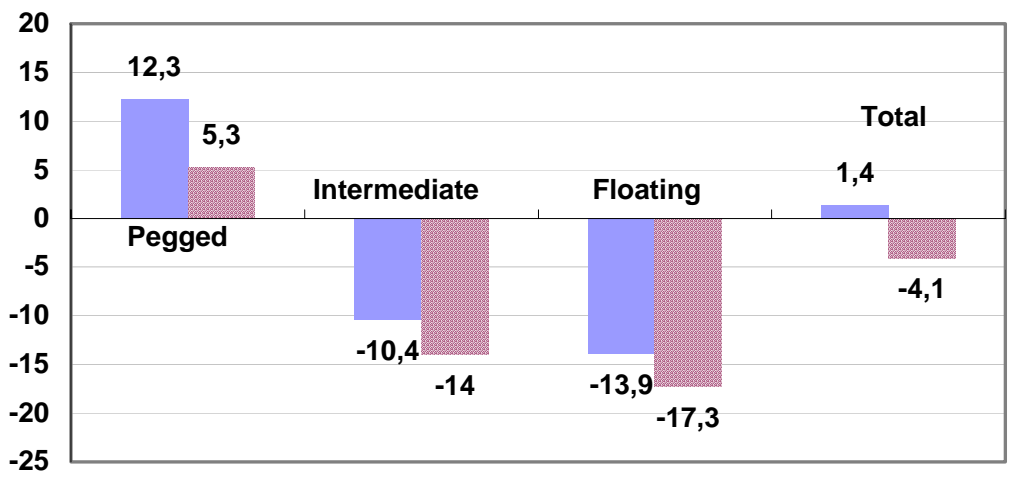

\section{$\underline{\text { RR classification }}$}

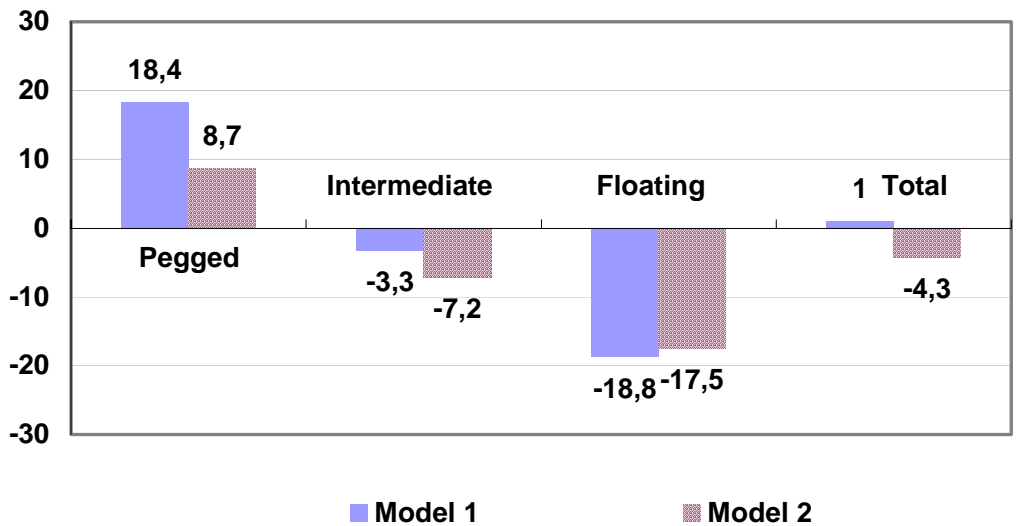

(1) Mean misalignment calculated by the two models according to exchange rate regimes in the two classifications.

Source: authors' calculations 
Differences between pegged and floating exchange rates are significant at a $1 \%$ significance level for the two classifications (Table 4). This means that overvaluation is more pronounced in the pegged exchange rate regimes. The result is robust to the change in classification. The case for intermediate regimes is not so clear-cut. The currencies in intermediate ERR are found less undervalued than floating currencies in the two classifications, but the difference is significant only in the RR classification. This may be due to the much greater number of observations classified as such in this latter classification (1161 versus 568).

Table 4: Tests of comparison of means between two categories of ERR: Pegged or intermediate exchange rate versus floating ${ }^{(1)}$, models 1 and 2.

\begin{tabular}{|c|c|c|c|c|}
\hline & $\begin{array}{c}\text { Pegged versus } \\
\text { floating }\end{array}$ & p-value ${ }^{(2)}$ & $\begin{array}{c}\text { Intermediate } \\
\text { versus floating }\end{array}$ & p-value ${ }^{(2)}$ \\
\hline \multicolumn{5}{|c|}{ LYS classification } \\
\hline Model 1 & 9.94 & 0.000 & 1.20 & 0.230 \\
\hline Model 2 & 9.62 & 0.000 & 1.30 & 0.195 \\
\hline \multicolumn{5}{|c|}{ RR classification } \\
\hline Model 1 & 11.0 & 0.000 & 4.7 & 0.000 \\
\hline Model 2 & 8.6 & 0.000 & 3.4 & 0.000 \\
\hline
\end{tabular}

(1) $t=\left(\bar{X}_{k}-\bar{X}_{0}\right) / \sqrt{\bar{S}_{k}^{2} / n_{i}+\bar{S}_{0}^{2} / n_{0}} \quad ; H 0=$ mean of $X$ is equal in two sub-samples of pegged ERR (or intermediate) and floating ERR., (2) Probability of being wrong when rejecting $\mathrm{H}_{0}$.

Source: authors’ calculations

We check if the results are robust to sub-samples of countries with different levels of inflation. High inflation countries are more likely to choose floating exchange rates, in order to let their currency depreciate along with their rising prices. This could also affect the behaviour of the real exchange rate. Consequently, we split up the sample into two types of observations: those of countries having moderate inflation (smaller than $40 \%$ ) and those of countries with high inflation (higher than 40\%). This is the threshold chosen by Reinhart and Rogoff (2004) for defining high inflation countries in their classification. Indeed, a first look at the results shows that this decomposition is relevant, for on the whole sample, high inflation countries have much more undervalued currencies than the others. Their currencies are undervalued by 10 to $11 \%$ in both models and both classifications (2 last bars in the second row of 2 graphs in Figure 3) against 0 to 6\% in "moderate" inflation countries (2 last bars in the first row of 2 graphs in Figure 3). 
Figure 3: Overvaluation by category of ERR and country’s inflation, in \% (1), according to models 1 and 2in LYS and RR classifications

\section{LYS classification}
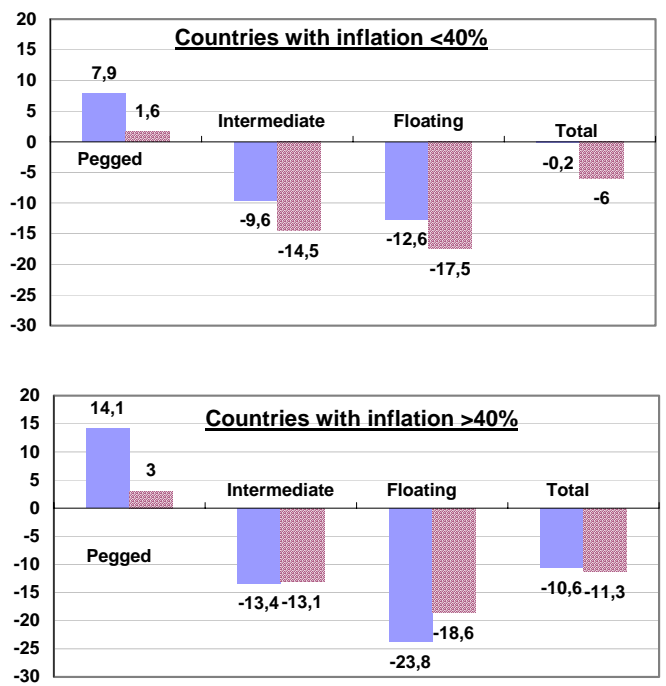

\section{$\underline{\text { RR classification }}$}
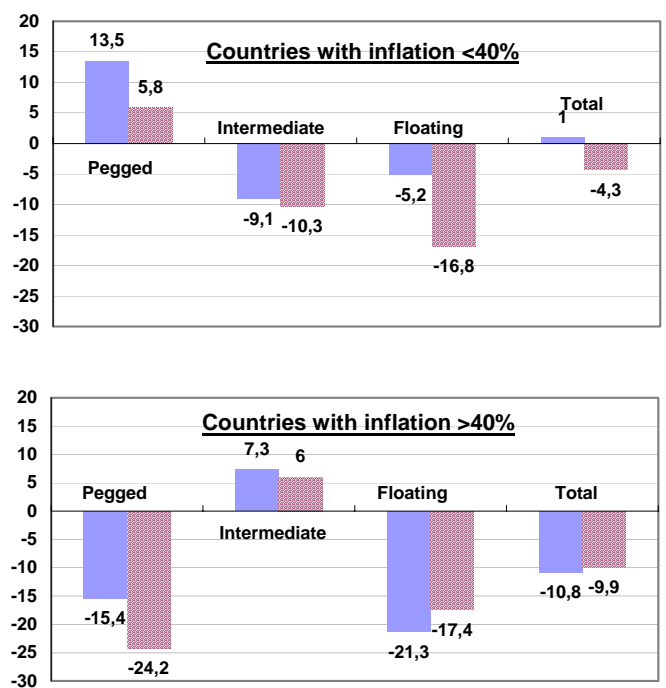

Model 1

Model 2

(1) Mean misalignment calculated by the two models according to exchange rate regimes and to country's inflation.

\section{Source: authors' calculations}

For countries with moderate inflation, all our previous results are confirmed: pegged currencies are overvalued when compared to floating currencies (First row of graphs in Figure 3). For example, taking into account the LYS classification, we see that fixed currencies are overvalued by $8 \%$ in model 1 , against an undervaluation of $13 \%$ for floating currencies ( First graph in first row in Figure 3). This remains true when changing models and classifications. Table 5 shows that the differences are significant in all cases. On the contrary, for high inflation countries, misalignments do not appear so different across exchange rate regimes, especially in the RR classification. On the whole, this splitting of the sample allows us to conclude that the previous results were not driven by abnormal values in high inflation countries. 
Currency Misalignments and Exchange Rate Regimes in Emerging and Developing Countries

Table 5: Tests of comparison of means between two categories of ERR: Pegged or intermediate exchange rate versus floating ${ }^{(1)}$, models 1 and 2

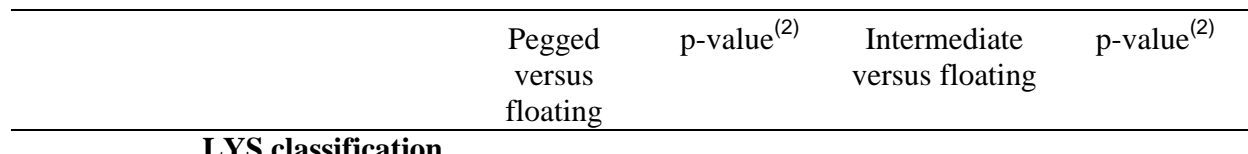

Moderate inflation countries

Model 1

$\begin{array}{llll}7.39 & 0.000 & 0.93 & 0.352\end{array}$

Model 2

7.73

0.000

1.05

0.294

$\underline{\text { High inflation countries }}$

Model 1

$\begin{array}{llll}2.51 & 0.012 & 1.52 & 0.128 \\ 1.58 & 0.114 & 0.87 & 0.385\end{array}$

Model 2

$1.58 \quad 0.114$

0.87

RR classification

Moderate inflation countries

Model 1

$\begin{array}{llll}3.15 & 0.002 & -0.66 & 0.506\end{array}$

Model 2

4.35

0.000

1.26

0.209

$\underline{\text { High inflation countries }}$

Model 1

0.46

0.642

4.33

0.000

Model 2

$-0.76$

0.444

4.09

0.008

(1) $t=\left(\bar{X}_{k}-\bar{X}_{0}\right) / \sqrt{\bar{S}_{k}^{2} / n_{i}+\bar{S}_{0}^{2} / n_{0}} \quad ; H 0=$ mean of $X$ is equal in two sub-samples of pegged ERR (or intermediate) and floating ERR.,(2) Probability of being wrong when rejecting $H_{0}$.

Source: authors' calculations

\section{CONCLUSION}

Pegged exchange rates are often pointed out as more prone to overvaluation, because their real exchange rates tend to appreciate. We check this assumption empirically over a large sample of countries spanning the period 1974-2004. We assess currency misalignments by estimating real equilibrium exchange rates using two cointegration relationships: the first one taking into account only a sheer Balassa effect, the second one adding the impact of net foreign assets. We then use two de facto classifications by Levy-Yeyati and Sturzenegger (2003) and by Reinhart and Rogoff (2004). Pegged currencies are evidenced to be significantly more overvalued than floating ones in both models. This result is also true when switching classification method. 


\begin{abstract}
APPENDIX
List of 128 countries for the estimations of currency misalignments in section 2

Albania, Algeria, Antigua and Barbuda, Argentina, Armenia, Australia, Austria, Azerbaijan, Bahrain, Bangladesh, Belarus, Belgium, Benin, Bolivia, Botswana, Brazil, Bulgaria, Burkina Faso, Cambodia, Cameroon, Canada, Chad, Chile, China P.R.Mainland, China P.R. Hong Kong, Colombia, Dem. Rep. of Congo, Republic of Congo, Costa Rica, Côte d'Ivoire, Croatia, Cyprus, Czech Republic, Denmark, Dominican Republic, Ecuador, Egypt, El Salvador, Estonia, Ethiopia, Finland, France, Gabon, Georgia, Germany, Ghana, Greece, Guatemala, Guinea-Bissau, Haiti, Honduras, Iceland, India, Indonesia, Iran, Ireland, Israel, Italy, Jamaica, Japan, Jordan, Kazakhstan, Kenya, Korea, Kyrgyz Republic, Lao, Latvia, Lithuania, Luxembourg, Macedonia, Madagascar, Malawi, Malaysia, Mali, Mauritius, Mexico, Moldova, Morocco, Mozambique, Myanmar, Namibia, Nepal, Netherlands, New Zealand, Nicaragua, Niger, Nigeria, Norway, Oman, Pakistan, Panama, Papua New Guinea, Paraguay, Peru, Philippines, Poland, Portugal, Qatar, Romania, Russia, Rwanda, Saudi Arabia, Senegal, Singapore, Slovak Republic, Slovenia, South Africa, Spain, Sri Lanka, Sudan, Swaziland, Sweden, Switzerland, Syrian Arab Republic, Tanzania, Thailand, Togo, Trinidad and Tobago, Tunisia, Turkey, Uganda, Ukraine, United Kingdom, Uruguay, Venezuela, Yemen, Zambia, Zimbabwe.
\end{abstract}

In Section 3, we focus on emerging and developing countries, defining them as countries with PPP GDP per capita smaller than $70 \%$ of the US level in year 2000. This leaves us with 108 countries, excluding the following ones from the former sample : Australia, Austria, Belgium, Canada, China P.R. Hong Kong, Denmark, Finland, France, Germany, Iceland, Ireland, Israel, Italy, Japan, Netherlands, Norway, Qatar, Sweden, Switzerland, United Kingdom. 


\section{REFERENCES}

Alberola, E., Cervero, S.G., Lopez, H. and A. Ubide, 1999, Global equilibrium exchange rates: Euro, Dollar, 'ins', 'outs' and other major currencies in a panel cointegration framework, IMF Working Paper 99/175.

Balassa, B. (1964), “The Purchasing Power Parity: a Reappraisal”, Journal of Political Economy, vol. 72, n6, pp. 584-596.

Bénassy-Quéré, A., Duran-Vigneron, P., Lahrèche-Révil, A. and V. Mignon, 2004, "Distributing Key Currency Adjustment: A G-20 panel cointegration approach", Institute for International Economics workshop on Dollar Adjustment: How Far? Against What?, May 25, Washington DC.

Bénassy-Quéré, A., S. Béreau and V. Mignon, 2008, How Robust are Estimated Equilibrium Exchange Rates? A Panel BEER Approach, CEPII Working Paper 200801.

Bubula, A. and I. Ötker-Robe (2002), “The evolution of exchange rate regimes since 1990: evidence from de facto pegs”, IMF Working Paper WP/2002/155.

Burkart, O. and V. Coudert, 2002, Leading indicators of currency crises for emerging countries », en collaboration avec O., Emerging Markets Review, Volume 3, Issue 2, 01June-2002.

Bussière, M. and M. Fratzscher, 2006, Towards a new Early Warning System of financial crises, Journal of International Money and Finance 25(6): 953-973, October.

Calvo, G. and C. Reinhart, 2000, “Fixing for your life”, NBER, WP No. 8006.

Calvo, G. and C. Reinhart, 2002, “Fear of floating”, Quarterly Journal of Economics 117, pp. 379-408.

Cheung,Y.-W., M. D. Chinn, E. Fujii, 2007, The overvaluation of Renminbi undervaluation, Journal of International Money and Finance 26.

Chinn, M. , 2000, Before the Fall: Were East Asian Currencies Overvalued?" Emerging Markets Review1 (2).

Chinn, M., and E. Prasad, 2003, "Medium-Term Determinants of Current Accounts in Industrial and Developing”, Journal of International Economics 59(1):47-76.

Clark, Peter and MacDonald, Ronald, 1998, "Exchange rates and economic fundamentals : a methodological Comparison of BEERs and FEERs”, IMF Working Paper WP/98/67.

Coudert V. and Couharde, C., 2007, "Real Equilibrium Exchange Rate in China: is the Renminbi Undervalued?”, Journal of Asian Economics, 18, p. 568-594, 2007.

Dubas J., Lee, B.J., Nelson C.M., 2005 “Exchange rate classifications and growth”, NBER Worling Paper $n^{\circ} 11272$.

Edwards, S., 1994, "Real and Monetary Determinants of Real Exchange Rate Behavior: Theory and Evidence from Developing Countries”, in John Williamson (ed.), 
Estimating Equilibrium Exchange Rates, Institute for International Economics, Washington D.C., pp. 61-92.

Edwards, S., 1997. "The Mexican Peso Crisis? How Much Did We Know? When Did We Know It?," NBER Working Papers 6334, National Bureau of Economic Research.

Edwards, S, \& Savastano, Miguel A. 1999. "Exchange Rates in Emerging Economies: What Do We Know? What Do We Need to Know?," NBER Working Papers 7228, National Bureau of Economic Research.

Goldfajn, I. and R. Valdés, 1996, “The Aftermath of Appreciations,” NBER Working Paper No. 5650.

Hansen, B.E., 1992. “Regression with Non-Stationary Variances”, RCER Working Papers 331, University of Rochester - Center for Economic Research.

Im K. S., Pesaran M. H. and Shin, 2003, “Testing for unit roots in heterogeneous panels», Journal of Econometrics 115, pp. 53-74.

Isard, P., Equilibrium Exchange Rates: Assessment Methodologies, IMF WP07/296, 2007.

Isard, P. and Faruqee, H., 1998, "Exchange Rate Assessment - Extensions of the Macroeconomic Balance Approach”, IMF Occasional Paper no. 167.

Kaminsky, G., Lizondo, J and Reinhart, C., 1998, “Leading Indicators of Currency Crises”, IMF Staff Papers, Vol. 45 No. 1, March 1998, 1-48.

Lane, P and G.M. Milesi-Ferretti, 2007, The external wealth of nations mark II: Revised and extended estimates of foreign assets and liabilities, 1970-2004, Journal of International Economics, 73, 223-250.

Levy Yeyati E. and F. Sturzenegger, 2003, “A De Facto Classification of Exchange Rate Regimes: A Methodological Note” American Economic Review, Vol. 93, No. 4.

Levy Yeyati E. and F. Sturzenegger, 2005, “Classifying Exchange Rate Regimes: Deeds vs. Words”, European Economic Review, Volume 49, Issue 6, August.

Milesi-Ferretti, G. and Razin, A. 1996, "Sustainability of Persistent Current Account Deficits”, NBER working paper 5467.

Montiel, P. 1999a, The Long Run Equilibrium Real Exchange Rate: Conceptual Issues and Empirical Research, in L. Hinkel and P. Montiel, eds, Exchange Rate Misalignments, World Bank Research Publication.

Montiel, P. 1999b, Determinants of the Long Run Equilibrium Real Exchange Rate: an Analytical Model, in L. Hinkel and P. Montiel, eds, Exchange Rate Misalignments, World Bank Research Publication.

Peter J. Montiel, P and Lawrence E. Hinkle (1999), Exchange Rate Misalignment: Concepts and Measurement for Developing Countries, Oxford University Press.

Pedroni, P. 1999, “Critical Values for Cointegration Tests in Heterogenous Panels with Multiple Regressors”, Oxford Bulletin of Economics and Statistics, Special Issue, pp. 653-670. 
Pedroni, P. (2000), "Fully Modifed OLS for Heterogeneou s Cointegrated Panels", Advances in Econometrics 15 (2000), pp. 93-130.

Poirson, H. (2001), “How do countries choose their exchange rate regime?”, IMF Working Paper WP/01/46.

Reinhart C. and Rogoff, K., 2004, “The Modern History of Exchange Rate Arrangements: A Reinterpretation”, Quarterly Journal of Economics, Vol. CXIX No. 1, February, 1-48.

Rodrik, D. 2007, The Real Exchange Rate and Economic Growth:Theory and Evidence, J. F. Kennedy School of Government, Harvard University, mimeo.

Rogoff, K., 1996, “The purchasing parity puzzle”, Journal of Economic Literature, vol XXXIV, June.

Williamson, J., 1994, Estimating Equilibrium Exchange Rates, Institute for International Economics, Washington DC.

World Bank, 2007, International Comparison Program, 2003-2006 Handbook, http://web.worldbank.org/WBSITE/EXTERNAL/DATASTATISTICS/ICPEXT. 


\section{LIST OF WORKING PAPERS RELEASED BY CEPII ${ }^{8}$}

No

2008-06 The Euro and the Intensive and Extensive Margins of Trade: Evidence from French Firm Level Data

2008-05 On the Influence of Oil Prices on Economic Activity and Other Macroeconomic and Financial Variables

2008-04 An Impact Study of the EU-ACP Economic Partnership Agreements (EPAs) in the Six ACP Regions

2008-03 The Brave New World of Cross-Regionalism

2008-02 Equilibrium Exchange Rates: a Guidebook for the Euro-Dollar Rate

2008-01 How Robust are Estimated Equilibrium Exchange Rates? A Panel BEER Approach

2007-24 Testing the Finance-Growth Link: Is there a Difference between Developed and Developing Countries?

2007-23 Labor Migration: Macoeconomic and Demographic outlook for Europe and Neighborhood Regions

2007-22 Economic Geography, Spatial Dependence and Income Inequality in China

2007-21 Does FDI in Manufacturing Cause FDI in Business Services? Evidence from French Firm-Level Data

2007-20 Bilateral Trade of Cultural Goods

\section{Authors}

A. Berthou

\& L. Fontagné

F. Lescaroux

\& V. Mignon

L. Fontagné,

D. Laborde

\& C. Mitaritonna

A. Tovias

A. Bénassy-Quéré,

S. Béreau

\& V. Mignon

A. Bénassy-Quéré,

S. Béreau

\& V. Mignon

G. Dufrénot,

V. Mignon

\& A. Péguin-Feissolle

V. Borgy

\& X. Chojnicki

L. Hering

\& S. Poncet

B. Nefussi

\& C. Schwellnus

A.C. Disdier, S.H.T. Tai,

L. Fontagné

\& T. Mayer

\footnotetext{
8

${ }^{8}$ Working papers are circulated free of charge as far as stocks are available; thank you to send your request to CEPII, Sylvie Hurion, 9, rue Georges-Pitard, 75015 Paris, or by fax : (33) 0153685504 or by e-mail sylvie.hurion@ cepii.fr. Also available on: Iwwww.cepii.fr. Working papers with * are out of print. They can nevertheless be consulted and downloaded from this website.

${ }^{8}$ Les documents de travail sont diffusés gratuitement sur demande dans la mesure des stocks disponibles. Merci d'adresser votre demande au CEPII, Sylvie Hurion, 9, rue Georges-Pitard, 75015 Paris, ou par fax : (33) 0153685504 ou par e-mail_sylvie.hurion @ cepii.fr. Egalement disponibles sur : Ilwww.cepii.fr. Les documents de travail comportant * sont épuisés. Ils sont toutefois consultable sur le web CEPII.
} 
2007-19 China and India in International Trade: from Laggards to Leaders?

2007-18 How Remote is the Offshoring Threat

2007-17 Costs and Benefits of Euro Membership: a Counterfactual Analysis

2007-16 Location Decisions and Minimum Wages

2007-15 MIRAGE, Updated Version of the Model for Trade Policy Analysis Focus on Agriculture and Dynamics

2007-14 Mondialisation des services de la mesure à l'analyse

2007-13 How are wages set in Beijing?

2007-12 IMF Quotas at Year 2030

2007-11 FDI and Credit Constraints: Firm Level Evidence in China

2007-10 Fiscal Policy in Real Time

2007-09 Global Ageing and Macroeconomic Consequences of Demographic Uncertainty in a Multi-regional Model

2007-08 The Effect of Domestic Regulation on Services Trade Revisited

2007-07 The Location of Domestic and Foreign Production Affiliates by French Multinational Firms

2007-06 Specialisation across Varieties within Products and North-South Competition

2007-05 Trade Costs and the Home Market Effect

2007-04 The Impact of Regulations on Agricultural Trade: Evidence from SPS and TBT Agreements
F. Lemoine

\& D. Ünal-Kesenci

K. Head, T. Mayer

\& J. Ries

E. Dubois,

J. Héricourt

\& V. Mignon

I. Méjean

\& L. Patureau

Y. Decreux

\& H. Valin

I. Bendisoun

\& D. Ünal-Kesenci

J. De Sousa

\& S. Poncet

A. Bénassy-Quéré,

S. Béreau,

Y. Decreux, C. Gouel

\& S. Poncet

J. Héricourt \& S. Poncet

J. Cimadomo

J. Alho \& V. Borgy

C. Schwellnus

T. Mayer, I. Méjean \& B. Nefussi

L. Fontagné,

G. Gaulier

\& S. Zignago

M. Crozet

\& F. Trionfetti
A.-C. Disdier,
L. Fontagné
\& M. Mimouni 
2007-03 International Comparisons of Living Standards by Equivalent Incomes

2007-02 Does Risk Aversion Drive Financial Crises? Testing the Predictive Power of Empirical Indicators

2007-01 Asian Catch Up, World Growth and International Capital Flows in the XXIst Century : A Prospective Analysis with the INGENUE 2 Model

2006-27 Current Account Reversals and Long Term Imbalances: Application to the Central and Eastern European Countries

2006-26 On Legal Origins and Brankruptcy Laws: the European Experience (1808-1914)

2006-25 Taux d'intérêt et marchés boursiers : une analyse empirique de l'intégration financière internationale

2006-24 Changing Patterns of Domestic and Cross-Border Fiscal Policy Multipliers in Europe and the US

2006-23 Market Access Impact on Individual Wage: Evidence from China

2006-22 FDI in Chinese Cities: Spillovers and Impact on Growth

2006-21 Are Financial Distortions an Impediment to Economic Growth? Evidence from China

2006-20 World Consistent Equilibrium Exchange Rates

2006-19 Institutions and Bilateral Asset Holdings

2006-18 Vertical Production Networks: Evidence from France

2006-17 Import Prices, Variety and the Extensive Margin of Trade

2006-16 The Long Term Growth Prospects of the World Economy: Horizon 2050

2006-15 Economic Integration in Asia: Bilateral Free Trade Agreements Versus Asian Single Market
M. Fleurbaey \&

G. Gaulier

V. Coudert \& M. Gex

M. Aglietta, V. Borgy, J. Château,

M. Juillard, J. Le

Cacheux, G. Le

Garrec \& V. Touzé

K. Benhima

\& O. Havrylchyk

J. Sgard

V. Borgy \& V. Mignon

A. Bénassy-Quéré \& J. Cimadomo

L. Hering \& S. Poncet

N. Madariaga \& S. Poncet

A. Guariglia

\& S. Poncet

A. Bénassy-Quéré, A. Lahrèche-Révil \& V. Mignon

V. Salins

\& A. Bénassy-Quéré

M. Fouquin,

L. Nayman

\& L. Wagner

G. Gaulier

\& I. Méjean

S. Poncet

M. H. Bchir \& M. Fouquin 


\section{CEPII \\ DOCUMENTS DE TRAVAIL / WORKING PAPERS}

Si vous souhaitez recevoir des Documents de travail, merci de remplir le coupon-réponse ci-joint et de le retourner à :

Should you wish to receive copies of the CEPII's Working papers, just fill the reply card and return it to:

Sylvie HURION - Publications

CEPII - 9, rue Georges-Pitard - 75740 Paris - Fax : (33) 1.53.68.55.04

sylvie.hurion@cepii.fr

M./Mme / Mr./Mrs

Nom-Prénom / Name-First name

Titre / Title .....

Service / Department

Organisme / Organisation

Adresse / Address.

Ville \& CP / City \& post code.

Pays / Country. Tél.

Your e-mail

Désire recevoir les Document de travail du CEPII $n^{\circ}$ :

Wish to receive the CEPII's Working Papers No:

Souhaite être placé sur la liste de diffusion permanente (pour les bibliothèques)

Wish to be placed on the standing mailing list (for Libraries). 